\title{
METODE PENANAMAN NILAI SOSIAL PADA SANTRI DI PONDOK PESANTREN SALAFIYAH DAN IMPLEMENTASINYA DALAM KEGIATAN MASYARAKAT PULUTAN LOR RW 02 KECAMATAN SIDOREJO KOTA SALATIGA TAHUN 2018
}

\author{
Oleh : \\ Jamasri \\ Universitas Kristen Satya Wacana Salatiga \\ e-mail: jamasri0693@gmail.com \\ Yosaphat Haris Nusarastriya \\ Universitas Kristen Satya Wacana Salatiga \\ e-mail: haris.nusa@staff.uksw.edu
}

\begin{abstract}
This study is titled the method of planting social value in santri at the Salafiyah Islamic Boarding School RW 02, Sidorejo sub-district, Salatiga city in 2018. This type of research is a qualitative descriptive study with 45 research subjects as kyai and santri. Data was collected by observation, interviews, documentation, and questionnaires. Data analysis using qualitative descriptive techniques. The results showed that the method of planting social values used was the Sorogan and Bandongan methods. The embedded social values include discipline, empathy, respect, caring, and tolerance. The implementation of the social values of santri in community activities is to become a TPA worker, a large study committee and mutual cooperation.
\end{abstract}

Keywords: social values, santri, islamic boarding schools, community activities 


\section{PENDAHULUAN}

\section{A. Latar Belakang Masalah}

Pendidikan menurut UU No. 20

Tahun 2003 adalah usaha sadar dan terencana untuk mewujudkan suasana belajar dan proses pembelajaran agar peserta didik secara efektif mengembangkan potensi dirinya untuk memiliki kekuatan spiritual keagamaan, pengendalian diri, kecerdasan, akhlak mulia, serta keterampilan yang diperlukan dirinya, masyarakat, bangsa, dan negara. Pendidikan di Indonesia terbagi menjadi dua yaitu pendidikan formal (SD, SMP, SMA) dan pendidikan non formal (Madrasah, Pondok Pesantren). Pendidikan formal menggunakan kurikulum umum yang minim dengan materi agama, sedang pendidikan madrasah memadukan kurikulum pendidikan formal dan pendidikan agama. Pondok pesantren dengan segala upaya untuk menjaga agar tetap eksis dalam dunia pendidikan mengembangkan model pendidikan pondok pesantren yang setara dengan sekolah formal atau pondok pesantren modern. Menurut Tuanaya dkk (2007:13) Pondok pesantren adalah institusi sosial yang mempunyai misi pendidikan dan sosial kemasyarakatan. Salah satu misi pendidikan di pondok pesantren adalah mengajarkan berdakwah, sehingga secara tidak langsung santri yang berada di pondok pesantren tidak dapat dipisahkan hubungan sosialnya dengan masyarakat yang berada di sekitar pondok pesantren yang dalam bahasa keilmuan disebut interaksi sosial. Pesantren diartikan sebagai asrama, tempat santri, atau tempat murid-murid belajar mengaji. Selain mendalami ilmu agama santri juga mendapatkan ilmu sosial kemasyarakatan, dengan ilmu sosial yang didapatkan tersebut diharapkan santri dapat menginternalisasikan dan mengimplementasikan dalam kehidupan masyarakat. Internalisasi adalah proses memasukan nilai pada seseorang yang akan membentuk pola pikir dalam melihat makna realitas pengalaman, sedangkam implementasi adalah mewujudkan nilai sosial tersebut dalam perilaku bersosial dengan masyarakat sekitar. Nilai sosial menurut Menurut Zubaedi (2005:13) adalah suatu nilai yang memberikan pedoman bagi masyarakat untuk hidup berkasih sayang dengan sesama manusia, berdampingan, harmonis, berdemokrasi dan bertanggung jawab, maka dari itu nilai sosial sangat penting bagi masyarakat, bangsa dan negara. Nilai-nilai sosial ini dibedakan dalam tiga macam yaitu: Keserasian hidup (Life harmony) terdiri atas nilai keadilan, toleransi, kerjasama, disiplin dan demokrasi. Kasih sayang (Loves) terdiri atas pengabdian, menghormati, tolong menolong, kekeluargaan, kesetiaan, dan kepedulian. Tanggung jawab (Responsibility) terdiri atas nilai rasa memiliki, simpati dan empati. Di tengah-tengah masyarakat para santri akan menjadi pimpinan umat dan sebagai warasatul anbiya (pewaris para nabi). Selain mengaji, santri di pondok pesantren juga dibekali dengan nilai- 
nilai sosial yang dipelajari dari kitab Khifayatul Akhyar dan Hadist tentang kehidupan sosial sehari-hari, tujuannya agar para santri siap untuk berbaur di masyarakat luas, begitu pula pada Pondok Pesantren Salafiyah para santrinya diberi penanaman nilai sosial oleh para Kyai/Ustadz. Berdasarkan penelitian yang relevan dari Ana Saifah Iqomatul Haq bahwa penanaman nilai sosial santri di pondok pesantren $\mathrm{Al}$ Huda Dlogo Candigatak Cempogo boyolali yaitu nilai kasih sayang, keserasian hidup dan tanggung jawab dengan tujuan untuk menghadapi masa depan dengan mempertahankan tradisi lama dalam pondok dan mengambil tradisi baru yang dianggap lebih baik untuk pengembangan kemajuan pondok pesantren Al Huda, sedangkan penelitian dari Muh Ulinuha dan teman-teman menunjukkan bahwa Internalisasi nilai sosial pada kalangan santri di pondok pesantren Raudlatut Tholibin pada masyarakat Babakan Kecamatan Ciwaringin Kabupaten Cirebon menunjukkan bahwa pola hidup santri mandiri, disiplin dan sederhana maka internalisasi nilai sosial dalam diri santri merupakan kewajiban bagi pengasuh, adanya pengawasan ekstra ketat supaya selepas dari pondok santri dapat menjadi pemimpin para umat sebagai Warasatul Anbiya (pewaris para nabi). Berdasarkan 2 penelitian tersebut maka nilai sosial yang internalisasikan dari santri kemasyarakat adalah nilai kedisiplinan, tanggung jawab, kasih sayang dan keserasian hiduppenelitian ini dilakukan dalam rangka untuk mengetahui metode sosial apa saja yang ditanamkan pada santri dan akan diimplementasikan dalam kegiatan bermasyarakat.

\section{B. Rumusan Masalah}

Beberapa permasalahan yang dirumuskan dalam penelitian ini adalah sebagai berikut:

1. Bagaimana metode penanaman nilai sosial pada santri dalam kegiatan mengaji di pondok pesantren Salafiyah?

2. Apa saja nilai-nilai yang ditanamkan pada santri?

3. Bagaimana implementasi nilai sosial oleh santri dalam kegiatan masyarakat Pulutan?

4. Apa saja faktor pendukung da penghambat dalam penanaman nilai sosial para santri?

\section{Tujuan Penelitian}

Tujuan yang hendak dicapai melalui penelitian ini dengan berdasarkan pada rumusan masalah sebagaimana tersebut di atas adalah untuk mengetahui 1) metode penanaman nilai sosial pada santri dalam kegiatan mengaji di pondok pesantren Salafiyah, (2) mengetahui nilai-nilai sosial yang ditanamkan pada santri, (3) implementasikan nilai sosial oleh santri dalam kegiatan masyarakat Pulutan, serta (4) faktor pendukung dan penghambat dalam penanaman nilai sosial pada santri. 
METODE PENELITIAN

Metode

penelitian ini menggunakan deskriptif kualitatif. Menurut Sugiyono (2012:1) metode penelitian kualitatif sebagai metode penelitian yang digunakan untuk meneliti pada kondisi obyek yang alamiah, (sebagai lawannya adalah eksperimen) dimana peneliti adalah sebagai instrumen kunci, teknik pengumpulan data dilakukan secara trianggulasi (gabungan), analisis data bersifat induktif, dan hasil penelitian kualitatif lebih menekankan makna dari pada generalisasi. Pendekatan metode deskriptif kualitatif dipilih karena mengarah kepada pendeskripsian secara mendalam dan rinci mengenai gambaran kondisi sebenarnya yang terjadi di lapangan.

Subyek dalam penelitian ini adalah Kyai dan para santri pondok pesantren Salafiyah yang berjumlah 45 santri putra dan putri, informan dalam penelitian ini adalah lurah Pondok Pesantren Salafiyah ,Kyai/Ustadz, santri dan masyarakat Pulutan lor kota Salatiga. Metode pengumpulan data yang digunakan dalam penelitian ini adalah metode Observasi untuk mengamati, mendengar dan mencatat kegiatan para santri. Metode wawancara digunakan untuk mengetahui lebih jauh mengenai kehidupan internal (di dalam pondok) dan eksternal (di luar pondok) dari santri dan cara-cara penanaman nilainilai sosial dari Kyai/ustadz kepada para santri untuk berbaur dengan masyarakat. Teknik Koesioner digunakan untuk memperoleh informasi dari responden dalam arti laporan tentang pribadinya atau hal-hal yang ia katahui. Metode dokumentasi bertujuan untuk mengambil data dokumen yang berkaitan dengan metode penanaman nilai sosial pada santri. Metode keabsahan data menggunakan metode triangulasi. Triangulasi yan digunakan dalam penelitian ini adalah triangulasi teknik dengan cara peneliti menggunakan teknik pengumpulan data yang berbeda-beda untuk mendapatkan data dari sumber yang sama triangulasi sumber berarti peneliti mendapatkan data dari sumber yang berbeda-beda dengan teknik yang sama. 


\section{HASIL PENELITIAN DAN PEMBAHASAN}

Seperti dipondok pesantren pada umumnya Pondok Pesantren Salafiyah Pulutan menggunakan metode pengajaran mengaji sorogan (individu) dan bandongan (klasikal). Bandongan merupakan bentuk belajar mengajar dengan cara ustadz membaca kitab kuning yang dikaji, dimaknai dan diterangkan sedangkan para santri menyimak dan menulis arti per kata yang penting pada suatu kitab. Kitab yang dikaji hanya satu jenis kitab kuning (kitab tanpa harokat). Selain kegiatan mengaji santri Shalafiyah juga mempunyai kegiatan-kegiatan rutin yang masih dilakukan hingga saat ini yaitu : Shalat Tahajud dan Duha, kegiatan kitobah, Al barzanji dan Rebana, Ziarah kubur, anjangsana, Tahlilan dan lain sebagainya. Salah satu motto dari Pondok Pesantren Salafiyah yaitu Khoirunnas Anfa'uhum Linnas yang mempunyai arti sebaik-baiknya manusia ialah yang bisa memberi manfaat terhadap orang lain, maka dari itu para pengasuh pondok pesantren selalu berpesan kepada santri untuk terus belajar agar ilmu yang di dapat bisa bermanfaat untuk diri sendiri (santri) dan orang lain (masyarakat).

Mewujudkan keseimbangan kemampuan keilmuan keislaman dan kemampuan bermasyarakat merupakan visi didirikannya Pondok Pesantren Salafiyah, karena dengan perkembangan zaman yang begitu pesat masyarakat memerlukan seorang santri sebagai pembimbing ibadah Mahdzoh maupun Ghoiru mahdzoh. Maka dari itu santri selain mendapat ilmu agama yang kental juga diimbangi dengan ilmu sosial kemasyarakatan. Nilai-nilai sosial tersebut dapat memberikan dampak positif terhadap kehidupan bermasyarakat. Adanya rasa kasih sayang, toleransi antar umat beragama, disiplin dan bertanggung jawab akan menciptakan sebuah kerukunan antar masyarakat demi terciptanya kehidupan yang harmonis dan saling peduli. Tanpa adanya nilai-nilai sosial, masyarakat akan lebih egois dan tidak memikirkan kehidupan orang lain, dan nilai sosial berfungsi sebagai alat untuk mengontrol tingkah laku manusia agar berperilaku sesuai dengan nilai yang dianutnya.

\section{Deskripsi Hasil Penelitian}

Penelitian yang dilakukan merupakan penelitian deskriptif kualitatif yang menggunakan dua variabel yaitu metode penanaman nilai sosial pada santri di Pondok Pesantren Salafiyah dan implementasinya ke dalam kegiatan masyarakat, penelitian ini melibatkan santri dan masyarakat Pulutan lor. Untuk mengetahui bagaimana metode penanaman nilai sosial pada santri dan implementasinya dalam kegiatan masyarakat maka peneliti mengumpulkan data melalui observasi, wawancara, dokumentasi dan angket. Validitas data diuji melalui triangulasi sumber, metode dan rentang waktu.

Uraian berikut merupakan penjelasan hasil penelitian yang berkaitan dengan kegiatan penanaman nilai sosial santri dan kegiatan dengan masyarakat sekitar Pondok Salafiyah. Penanaman nilai sosial pada santri diberikan dari 
Ustadz/Kyai saat kegiatan mengaji, yang sudah terjadwal sesuai dengan waktu. Kitab yang dibahas dalam kegiatan mengaji antara lain setelah maghrib setelah isya' dan setelah subuh. Dalam metode sorogan santri tidak hanya menulis arti dalam kitab akan tetapi santri juga diminta untuk memahami dan memberikan contoh kegiatan sosial dalam kehidupan sehari-hari agar santri bisa lebih mengerti makna dan kandungan nilai-nilai sosial yang ada dalam kitab tersebut. Disamping melalui kegiatan pembelajaran mengaji, penanaman nilai sosial pada santri juga dilakukan melalui keteladanan, penguatan positif dan negatif, simulasi bermain peran, pembiasaan, pengkondisian.

Dengan menggunakan metode mengaji bandongan dan sorogan para santri diarahkan supaya tidak hanya paham akan memaknai isi sebuah kitab tapi juga paham akan pelaksanaan kegiatan sosial seharihari. Nilai sosial yang ditanamkan oleh seorang Ustadz/Kyai bersumber dari kitab yang dibahas meliputi nilai keserasian hidup, nilai kasih sayang dan nilai tanggung jawab contoh gotong royong, tolong menolong, bertoleransi antar umat manusia dan kegiatan sosial yang lain. Melalui penanaman nilai-nilai yang bersumber pada kitab tersebut diharapkan santri memiliki sikap dan perilaku yang berbudi pekerti luhur. santri tidak hanya mengikuti kegiatan intern pondok tetapi juga mengikuti kegiatan ekstern pondok Kegiatan sosial kemasyarakatan yang dilakukan oleh para santri sebagai bentuk implementasi nilai sosial yang ditanamkan di Pondok Pesantren Salafiyah misalnya kegiatan gotong royong, bersihbersih masjid, trotoar jalan sekitar masjid dan bersih kubur. Sebagai tenaga TPA (Taman Pendidikan Al Quran) bermodalkan keahlian mengaji para santri secara terjadwal ikut membantu warga sekitar dengan cara menjadi tenaga pendidik di Taman Pendidikan Al Qur'an di daerah Pulutan lor. Kegiatan kemanusiaan yang dilakukan oleh para santri yaitu ikut berpartisipasi jika ada masyarakat sekitar pondok yang sedang tertimpa musibah seperti kematian, para santri ikut membantu proses pelaksanaan pemakaman jenazah. Selain hasil pengamatan, wawancara dan dokumentasi diatas juga didukung dengan hasil angket quisioner yang diisi oleh 45 santri putra/putri Pondok Pesantren Shalafiyah yang menunjukkan implementasi nilai sosial oleh santri dalam kegiatan masyarakat Pulutan lor antara lain implementasi nilai keserasian hidup meliputi kerjasama, toleransi, kedisiplinan, nilai kasih sayang meliputi tolong menolong, kepedulian dan nilai tanggung jawab meliputi simpati, empati. Berdasarkan pengolahan angket, dapat dijelaskan sebagai berikut:

Prosentase setiap indikator diperoleh dengan cara membandingkan skor yang diperoleh dengan skor maksimum dikalikan $100 \%$. Skor maksimum, misalkan dari $=45$ (Responden) $\times 4$ (Nilai Maksimum) x 3 (butir soal nilai gotong royong) $=540$. Hasil implementasi nilai sosial santri dalam kegiatan sosial kemasyarakatan yaitu meliputi nilai kedisiplinan $74 \%$ dengan kategori baik, nilai simpati dan empati $77 \%$ 
dengan kategori baik, nilai menghormati $81 \%$ dengan kategori sangat baik, nilai kepedulian $82,5 \%$ dengan kategori sangat baik dan nilai toleransi $72,7 \%$ dengan kategori baik. Dapat disimpulkan bahwa prosentase implementasi nilai sosial santri Pondok Pesantren Salafiyah dalam kegiatan sosial kemasyarakatan mempunyai rentang nilai dari 72,7 s/d $82,5 \%$ dalam katagori baik. Berdasarkan hasil wawancara dengan para Kyai, santri dan beberapa warga masyarakat Pulutan lor serta observasi terhadap kegiatan kemasyarakatan yang dilakukan oleh santri secara langsung dan mendalam ditemukan beberapa faktor pendukung dan penghambat dalam melaksanakan penanaman nilai sosial pada santri dan implementasinya dalam kegiatan masyarakat. Ada faktor-faktor internal dan Eksternal yang mendukung dan menghambat terhadap penanaman nilai sosial pada santri dari para Ustadz/Kyai dan implementasinya dalam kegiatan masyarakat sekitar Pondok

Faktor pendukung dari Pondok untuk santri mendapatkan pendidikan ilmu agama dan ilmu sosial yaitu tersediannya fasilitas umum seperti mimbar masjid yang digunakan sebagai tempat mengaji dan kitabkitab yang disediakan oleh pengurus untuk proses pembelajaran dengan para santri. Pengajaran sengaja dilakukan diluar ruangan dengan maksud agar para pengurus dan santri bisa lebih dekat dengan warga atau para remaja yang juga ikut dalam kegiatan mengaji.

Masyarakat Pulutan sendiri mempunyai kegiatan rutinan yang dilaksanakan oleh masyarakat
Pulutan, santri dan kyai yaitu kegiatan Manaqib yang diadakan setiap malam Selasa kliwon. Kegiatan Dzibaan keliling yang dilaksanakan setiap akhir bulan secara berkeliling yang diadakan masyarakat Pulutan lor melibatkan santri pondok pesantren Salafiyah. Berdasarkan hasil penelitian menunjukkan bahwa penanaman nilai sosial yang diberikan oleh Kyai melalui sistem pengajaran pada saat mengaji dengan para santri menggunakan metode pengajaran sorogan dan bandongan. Sorogan adalah Suatu metode pengajaran dengan santri menyodorkan kitab untuk diterjemahkan dihadapan kyai atau badal, sedang bandongan adalah Suatu metode pengajaran dimana para santri mengikuti pelajaran dengan duduk di sekeliling kyai. Para santri tidak hanya sekedar memaknai isi dari sebuah kitab tetapi juga dapat memahami akan isi kandungan dalam kitab-kitab yang di pelajari. Kitab-kitab yang dipelajari santri dengan metode Sorogan antara lain kitab Bahjatul Wasail, Nashoihul 'Ibad, ilmu Falaq dan Al Qur'an. Metode Bandongan para santri harus bisa membaca, memaknai dan memberikan contoh dalam kehidupan sehari-hari. Kitab yang dibahas dengan metode Bandongan yaitu kitab Kifayatul Akhyar dan Sulam Taufiq. Dalam kegiatan mengaji para kyai secara langsung menanamkan nilai-nilai sosial bermasyarakat yang bersumber pada kitab, seperti menjalin hubungan yang harmonis dengan masyarakat, keserasian hidup dengan masyarakat, menanamkan rasa kasih, tolong menolong, dan sopan santun dengan masyarakat sekitar pondok. 
Disamping penanaman nilai sosial dalam kegiatan mengaji melalui metode Bandongan dan Sorogan, penanaman nilai sosial juga dilakukan dengan cara keteladanan, pembiasaan dan seterusnya. Santri di Pondok Pesantren Salafiyah diarahkan oleh para pengurus dan Kyai untuk menjalin keakraban dengan masyarakat sekitar pondok dengan mengikuti kegiatan-kegitan sosial kemasyarakatan. Hal ini juga dapat dilihat dari hasil olah data angket yang menyatakan bahwa hubungan santri dan masyarakat sekitar pondok terjalin dengan sangat baik dilihat dari implementasi nilai sosial dalam kegiatan sosial kemasyarakatan yaitu meliputi nilai kedisiplinan $74 \%$ dengan kategori baik, nilai simpati dan empati $77 \%$ dengan kategori baik, nilai menghormati $81 \%$ dengan kategori sangat baik, nilai kepedulian $82,5 \%$ dengan kategori sangat baik dan nilai toleransi $72,7 \%$ dengan kategori baik. Dari jumlah data tersebut maka dapat ditarik kesimpulan bahwa hubungan santri dengan Allah SWT, para pengurus pondok dan masyarakat sekitar pondok terbilang sangat baik. Sikap disiplin, simpati dan empati, menghormati, kepedulian dan bertoleransi yang didapat santri dalam pengajaran di pondok akan dijadikan bekal santri setelah akhirusanah dari pondok dan diterapkan dalam kehidupan bermasyarakat yang lebih luas.

Adapun faktor pendukung penanaman nilai sosial pada santri dalam kegiatan mengaji di pondok pesantren Salafiyah yaitu tersedianya tempat mengaji yaitu serambi masjid Asy Syarqowi, tersedianya kitabkitab yang disediakan oleh pengurus untuk santri ataupun remaja masjid untuk mengaji, dan aula putri untuk rapat internal santri pondok pesantren Salafiyah, sound system untuk berlatih Khitobah sehingga santri lebih mudah mendapatkan pengajaran agama dan nilai-nilai sosial untuk diimplementasikan dalam kegiatan masyarakat sekitar dengan sistem mengaji. Disamping itu, ada faktor pendukung yang berasal dari diri santri yaitu motivasi untuk belajar ilmu agama supaya bisa menjadi pribadi yang berguna bagi diri sendiri dan orang lain.

Selain faktor pendukung yang dimiliki oleh santri terdapat juga faktor penghambat santri untuk bersosial dengan masyarakat yaitu banyaknya tugas-tugas mandiri dari kampus yang membuat santri harus bisa membagi waktu untuk mengerjakan tugas kampus tepat pada waktunya dan tugas rutinan pondok. Karena mayoritas santri yang berada di Pondok Pesantren Salafiyah adalah mahasiswa di salah satu perguruan tinggi di Salatiga. Selanjutnya masyarakat sekitar pondok pesantren Salafiyah sangat mendukung kegiatan-kegiatan yang diadakan oleh santri pondok Salafiyah dengan cara masyarakat ikut serta dalam kegiatan yang diadakan oleh santri seperti kegiatan Zibaan, Yasinan, Manaqib, dan kegiatan sosial lainnya. Metode Penanaman Nilai sosial yang dilakukan di Pondok Pesantren Salafiyah yaitu menggunakan metode sorogan dan bandongan. Metode Sorogan yang dimaksud menyodorkan yaitu setiap santri bergilir menyodorkan kitab untuk diterjemahkan di hadapan Kyai atau badal (pembantunya). Dalam 
menggunakan metode sorogan ini para santri mengkondisikan dirinya untuk secara bergilir mengartikan dan menyampaikan kandungan makna dan nilai-nilai sosial yang terkandung dalam sebuah kitab serta bagaimana implementasi nilai sosial dalam kehidupan bermasyarakat. Sedangkan yang dimaksud metode Bandongan yaitu suatu metode pengajaran dimana para santri mengikuti pengajaran kitab dengan duduk disekeliling Kyai. Para santri menulis arti dari isi kitab yang sedang dibacakan oleh kyai, dan nilai-nilai sosial yang terkandung dalam kitab tersebut. Sehingga santri dapat memahami makna dan menerapkan nilai sosial dalam kehidupan bermasyarakat. Santri mengimplementasikan nilai sosial dalam kegiatan masyarakat Pulutan lor dengan cara para santri ikut berpartisipasi dalam kegiatan yang diadakan oleh masysrakat seperti gotong royong, tolong menolong jika ada masyarakat yang sedang tertimpa musibah seperti kematian, menjadi tenaga pendidik di Madrasah dan lain sebagainya. Faktor pendorong terlaksananya penanaman nilai sosial dalam kegiatan mengaji di pondok pesantren Salafiyah yaitu tempat tinggal (Pondok), tersedianya serambi masjid Asy Syarqowi, Aula pondok putri yang digunakan untuk rapat internal dan kegiatan mengaji santri, kitab-kitab yang disediakan pengurus untuk mengaji, adanya sound system yang digunakan santri untuk latihan khitobah. Adapun faktor penghambat dari santri yaitu pembagian waktu untuk mengerjakan tugas-tugas dan acara kampus yang harus segera diselesaikan. Faktor pendukung dari masyarakat dalam implementasi nilai sosial santri adalah keikutsertaan masyarakat pondok dalam mengikuti kegiatan yang diadakan oleh santri seperti Zibaan, Yasinan dan Manaqiban.

\section{KESIMPULAN DAN SARAN}

Bagi Kyai/Ustadz Metode penanaman nilai sosial oleh Kyai/Ustadz dalam kegiatan mengaji di Pondok Pesantren Salafiyah yaitu metode Bandongan dan Sorogan, kedua metode pengajaran tersebut harus dibiasakan untuk santri, karena dengan terbiasanya santri mengartikan dan menyampaikan isi kandungan dari sebuah kitab maka santri akan lebih paham dalam mengaplikasikan dalam kehidupan bermasyarakat dan siap menjadi seorang Warrasatul Anbiya'(pewaris para Nabi). Santri Pondok Pesantren Salafiyah untuk santri pondok pesantren Salafiyah harus bisa membagi waktu secara tepat antara kegiatan rutinan pondok dan kegiatan dari kampus, sehingga tidak mengganggu kegiatan Internal dan Eksternal pondok dan terus menjalin dan mempererat hubungan sosial dengan masyarakat sekitar pondok. 


\section{DAFTAR PUSTAKA}

Malik Tuanaya dkk. 2007. Modernisasi Pesantren. Jakarta: Balai Penelitian dan Pengembangan Agama Jakarta.

Sugiyono. 2012. Memahami penelitian kualitatif. Bandung : Alfa Beta 2013. Metode penelitian kuantitatif, kualitatif, dan $R \& D$. Bandung : Alfa Beta.

Zubaedi. 2005. Pendidikan Berbasis Masyarakat. Yogyakarta: Pustaka Pelajar. 